\title{
4
}

\section{The Role of Silica Fume Pigments in Corrosion Protection of Steel Surfaces}

\author{
Nivin M. Ahmed ${ }^{1}$ and Hesham Tawfik M. Abdel-Fatah ${ }^{2}$ \\ ${ }^{1}$ Polymers and Pigments Department, National Research Centre, Dokki, Cairo, \\ ${ }^{2}$ Central Chemical Laboratories, Egyptian Electricity Holding Company, Sabtia, Cairo,
}

Egypt

\section{Introduction}

Inorganic Pigments significantly change our surroundings. They are irreplaceable for serving the purpose of imparting color to various compounds. They also add properties such as rust inhibition, rigidity, and abrasion resistance. Pigments are insoluble substances that can be incorporated into a material to selectively absorb or scatter light. Depending on the specific pigment used, different visual effects are produced. Inorganic pigments may be obtained from a variety of naturally occurring or synthetically produced mineral sources. Their applications range from concrete to artist's colors, from industrial paints to toners in photocopiers, from coloring in foodstuffs to raw materials for catalysts. The application properties of pigments depend not only on their chemistry but also on their chemical appearance and to greater extent on the manufacture process (Barnett et al., 2006; Talbert, 2007; Brock, 2000; Baxbaum \& Pfaff, 2005).

In comparison with organic pigments, inorganic pigments are generally better to withstand the effects of sunlight and chemical exposure. They provide superior opacity, which means they can render a substance or object opaque by prohibiting light from passing through it. Inorganic colors, however, tend to be less bright, pure, and rich than their organic counterparts. Inorganic pigments also possess less tinting strength; i.e. more pigment is needed to produce the desired effect. This generally makes them more durable. Almost all inorganic pigments are completely insoluble. Consequently they do not bleed or leach out of coatings, inks, or plastics. In addition, inorganic pigments are usually less expensive than similar organic colors (Gysau, 2006; Brock et al., 2000; Baxbaum \& Pfaff, 2005; Degryse, 2003).

Nowadays there is evolution in pigment industry, manufacturers are trying to evolve new trends of pigments which are safe, cheap with high efficiency to replace the common and well known pigments, among these new trends of pigments are;

a. Substrate pigments, where at least one additional component (pigment or extender) is deposited onto a substrate (pigment or extender), preferably by a wet method. Weak, medium or strong attractive forces develop between these pigment components during drying or calcining. These forces prevent segregations between components during use (Baxbaum \& Pfaff, 2005; Degryse, 2003; Herbst\& Hunger 2006). 
b. Special substrate pigments include the after-treated pigments and the core pigments. To produce the after-treated pigments the inorganic pigment particles are covered with a thin film of inorganic or organic substances to suppress undesirable properties (e.g. catalytic and photochemical reactivity) or to improve the dispersibility of the pigments and the hydrophilic or hydrophobic character of their surfaces. The particles can be coated by precipitation, by adsorption of suitable substances from solutions (usually aqueous), or by steam hydrolysis (Baxbaum \& Pfaff, 2005; Degryse, 2003; Herbst\& Hunger 2006; Warson \& Finch, 2001; Forsgren, 2006; Vesely \&Kalendova, 2008). To produce core pigments. A pigment is deposited on an extender, by precipitation or by wet mixing of the components. In the case of anticorrosive pigments, whose protective effect is located on their surfaces, the use of core pigments can bring about a significant saving of expensive materials. Extender particles are also treated by fixing waterinsoluble organic dyes on their surfaces via lake formation (Vesely \&Kalendova, 2008; Veleva, 1999).

Titanium dioxide and silica are among the most frequently used fillers in paint and coating formulations. The special properties of the materials should improve the product formulation.

Silica fume is a byproduct of producing silicon metal or ferrosilicon alloys, Silicon metal and alloys are produced in electric furnaces. The smoke that results from furnace operation in tonnage amounts is collected and sold as silica fume, rather than being land-filled. Nowadays, there is increasing environmental concern with regard to excessive volumes of solid waste hazards accumulation. Silica fume which is a fine lightweight fluffy amorphous powder that possesses suitable values of specific gravity, bulking value and oil absorption can find a new market in different industries (Ayana et al, 2005). Silica fume is inert, neutral and of an excellent chemical resistance. It consists primarily of amorphous (non-crystalline) silicon dioxide $\left(\mathrm{SiO}_{2}\right)$; its amorphous nature favors safe use from a standpoint of industrial hygiene. It has spherical fine particles less than $0.01 \mu$, the average particle size ranges between 0.1-0.3 $\mu$, easy to lump together to form a looser, with high adsorption capacity and gel. Its average granule diameter is $0.15 \sim 0.20 \mu \mathrm{m}$, and specific surface area is 15000 20000 $\mathrm{m}^{2} / \mathrm{kg}$. Major Features of silica powder are its high purity $\left(\mathrm{SiO}_{2}\right.$ Content Above $\left.99.5 \%\right)$, hardness 7, high White Reached 96 Degrees, reasonable oil absorption, good dispersion, and stable chemical properties. It improves coatings corrosion resistance, wear resistance, and high temperature resistant properties (Del Amo et al, 2002; Perrera, 2004; Molera et al., 2004; Sorensen et al., 2009).

Silica fume is widely used in hydropower projects, refractories, roads, bridges, tunnels, chemical ceramic, rubber and other industries. Because of its fine particles, large surface area, and the high $\mathrm{SiO}_{2}$ content, silica fume is very reactive material. It can be successfully applied in raising intensity, durability, and it also can improve the material overall performance as filler, used in paint, coating, rubber and other high molecular material (kirubaharan et al., 2009; Guin et al., 2011; Siddique \& Khan, 2011, Weil, 2011).

The health problems concerning fumed silica are low; it is not listed as a carcinogen by OSHA, IARC, or NTP. Due to its fineness and thinness, fumed silica can easily become airborne, making it an inhalation risk, capable of causing irritation.

The extremely fine and non-porous nature of pyrogenic silica or fumed silica as it is also known, make it an ideal thickening and bulking agent with outstanding thixotropic 
qualities. Thixotropic refers to a substances characteristic of reducing viscosity or thickness with extended agitation or shaking. This makes fumed silica ideal filler for paints, thus causing them to thin out during application and regain their viscosity when left to stand preventing drips and runs. This characteristic is also beneficial in the formulation of printing inks which allow for high definition levels during application (Yingchao et al., 2011; Otterstedt \& Bradreth, 1998).

Silica fume products have very high purity resulting in highly consistent physical properties and particle size distributions. Their complete inertness and neutral $\mathrm{pH}$, make these products not capable of altering or initiating reactions when incorporated in catalyzed or multi-component chemical systems. Silica fume filler can be used in the following coating and paint industry field (Baxbaum \& Pfaff, 2005; Forsgren, 2006; Patton, 1973):

- Industry painting

- Wooding coating

- Anti-corruption coating

- Powder coating

- Architectural Paint

- Water -Proof Paint

Silica fume can benefit (Ayana, 2005; Kirubaharan, 2009):

- For improved abrasion resistance and scratch resistance of the film.

- Gives the highest chemical durability in industrial coatings.

- Offers high loading level leads to reduced formulation cost.

The modern coatings industry utilizes evolving chemistries in its quest to become more efficient in protecting and enhancing the various substrates to which coatings are applied. Further, in order to limit toxic and environmentally damaging emissions, the industry is striving to move away from solvents to water-based employing eco-friendly pigments. This is focused on providing some of the chemical solutions to the many challenges the industry face today in generating modern, safe, low-emission paints and coatings.

Titanium dioxide is a chemically very inert and light resistant material. $\mathrm{TiO}_{2}$ is mainly known as white pigment (so-called titanium white) and is valued for its brightening effects, and its dirt-repellent properties. $\mathrm{TiO}_{2}$ particles are used in the coatings industry because of its strong color, high opacity due to their high refractive index, improving the light resistance and dirt resistance of a formulation, low oil absorption, high tinting strength, inert chemical properties and recently attractively as photo-catalyst derived from their photo-catalytic activity. Although high photo-catalytic activity is required for titanium dioxide used as photo-catalysts, low photo-catalytic activity is sometimes preferred for titanium dioxide additives to avoid the degradation of matrix. The catalytic activity of titanium dioxide particles can be enhanced or suppressed by precipitating them on a core of other appropriate pigment to control this phenomenon. The insulating layers like silica $\left(\mathrm{SiO}_{2}\right)$, alumina $\left(\mathrm{Al}_{2} \mathrm{O}_{3}\right)$, or a polymer are often expected to suppress the catalytic activity of titanium dioxide particles (Peter \& Robert, 1999; Salamone, 1999; Streitberger \& Kreis, 2008; Martens, 1974; Bremmell \& Mensah, 2005).

The refractive index is a measure of how light is bent when it passes from one medium to another. The higher the refractive index, the more the light is bent which results in greater 
opacity. Rutile $\mathrm{TiO}_{2}$ has a high refractive index and gives good opacity to coatings. Most mineral fillers have a significantly lower refractive index than $\mathrm{TiO}_{2}$ and don't contribute to the opacity, but they can be used in conjunction with $\mathrm{TiO}_{2}$ to achieve opacity at reduced cost. Some minerals, such as amorphous silica (silica fume), have refractive index the same or lower than the resin and will be invisible in the dry film. They can be used to reduce the gloss of a clear coating without creating haze (Bremmell \& Mensah, 2005; Shao et al., 2009; Gaumet et al., 1997; Walter, 1991).

This work addresses preparation of new pigments via new method of preparation named "Core-shell", where silica fume which is a cheap and waste material representing the core comprises $90 \%$ of the new pigments is covered with a thin layer of titanium dioxide that does not exceed $10 \%$ of the pigment comprising the shell. This method of preparation presents a new easy route to obtain high performance pigments with concomitant savings besides being eco-friendly. Presence of titanium dioxide is expected to increase the hiding power of silica fume and consequently increases the new pigments opacity. The combination of these two compounds can lead to the production of new pigments with improved properties different from each of its individual components, overcoming their deficiencies; and consequently changing their efficiency of protection when applied in paints. Titanium dioxide was deposited on silica fume surface in three different concentrations to study the effect of its presence concentration on the anticorrosion efficiency of the new core-shell pigments.

\section{Experimental}

\subsection{Materials}

All the employed pigments, extenders, resins, solvents, additives and chemicals were products of different local and international companies.

Silica fume waste used has the following chemical composition.

\begin{tabular}{|c|c|}
\hline Concentration of main constituents & Wt., \% \\
\hline $\mathrm{SiO}_{2}$ & 95.54 \\
\hline $\mathrm{Al}_{2} \mathrm{O}_{3}$ & 0.34 \\
\hline $\mathrm{Fe}_{2} \mathrm{O}_{3}$ & 0.91 \\
\hline $\mathrm{MgO}$ & 0.70 \\
\hline $\mathrm{CaO}$ & 0.32 \\
\hline $\mathrm{Na}_{2} \mathrm{O}$ & 0.39 \\
\hline $\mathrm{K}_{2} \mathrm{O}$ & 0.80 \\
\hline $\mathrm{P}_{2} \mathrm{O}_{5}$ & 0.07 \\
\hline $\mathrm{SO}_{3}$ & 0.03 \\
\hline $\mathrm{L} . \mathrm{O} . \mathrm{I}$ & 4.93 \\
\hline
\end{tabular}

Table 1. Chemical composition of silica fume

\subsubsection{Preparation of $\mathrm{TiO}_{2} / \mathrm{SiO}_{2}$ fume core-shell pigments}

Titanium tetrachloride was added in three concentrations 1,2 and $3 \mathrm{ml}$ to $100 \mathrm{ml}$ hydrochloric acid. Silica was immersed in these three solutions and left for sometime to assure complete covering. Ammonia solution was added drop-wisely to these impregnated 
silicas to adjust their $\mathrm{pH}$; till complete precipitation of the pigments. The formed paste is then filtered through a buchner system and washed very well. This paste is then calcined at $500-750^{\circ} \mathrm{C}$. Three concentrations of titanium dioxide and consequently of titanium were deposited on silica surface, these three concentrations are shown in Table (2).

\begin{tabular}{|c|c|c|c|}
\hline Pigments & $\begin{array}{c}\text { Concentration of } \mathrm{TiCl}_{4} \\
\text { (wt. \%) }\end{array}$ & $\begin{array}{c}\text { Concentration of } \mathrm{TiO}_{2} \\
\text { (wt. \%) }\end{array}$ & $\begin{array}{c}\text { Concentration of Ti } \\
\text { (wt. \%) }\end{array}$ \\
\hline $\mathrm{TiO}_{2} / \mathrm{SiO}_{2}$ (1) & 1 & 0.42 & 0.25 \\
\hline $\mathrm{TiO}_{2} / \mathrm{SiO}_{2}(\mathbf{2})$ & 2 & 0.84 & 0.50 \\
\hline $\mathrm{TiO}_{2} / \mathrm{SiO}_{2}(\mathbf{3})$ & 3 & 1.26 & 0.76 \\
\hline
\end{tabular}

Table 2. Concentrations of titanium dioxide and titanium on silica surface

The scheme of preparation was as follows

$$
\mathrm{TiCl}_{4} / \mathrm{SiO}_{2} \underset{\mathrm{NH}_{4} \mathrm{OH}}{\rightarrow} \mathrm{TiOH}_{4} / \mathrm{SiO}_{2}+\mathrm{NH}_{4} \mathrm{Cl} \stackrel{\Delta}{\rightarrow} \mathrm{TiO}_{2} / \mathrm{SiO}_{2}
$$

\subsection{Specification of the physical-chemical properties of the prepared pigments}

\subsubsection{Specific gravity}

Determination of specific gravity was carried out according to (ASTM D5965-96, 2007).

\subsubsection{Oil absorption}

This was carried out by measuring the amount of flax oil in grams that makes a paste with defined properties out of $100 \mathrm{~g}$ of pigments. This determination was carried out using the pestle-bowl method according to (ASTM D281-95, 2007).

\subsubsection{Bulking value}

Determination of bulking value which expresses the volume of paint for a given weight of a pigment, in which pigments with higher bulking values are considered more economic, is carried out according to (ASTM D 16-62, 2007).

\subsubsection{Determining $\mathrm{pH}$ of the aqueous extracts of the pigments}

The procedure of determining aqueous extract $\mathrm{pH}$ was derived from a procedure according to (ASTM D 1583-01, 2007). Suspensions of the pigments were prepared in redistilled water.

\subsection{Methods of instrumental analysis}

\subsubsection{X-ray diffraction}

X-ray powder diffraction patterns were obtained at room temperature using a Philip's diffractometer (type PW1390), employing Ni-filtered $\mathrm{Cu} \mathrm{Ka}$ radiation $(\lambda=1.5404 \AA$ ). The diffraction angle, $2 \theta$, was scanned at a rate of $2^{\circ} / \mathrm{min}$. 


\subsubsection{SEM/EDAX analysis}

Energy-dispersive X-ray analysis technique, and scanning electron microscopy, (JEOL JX 840), micro-analyzer electron probe, was used in this work to estimate the particle shapes and to determine the elements deposited on silica surface to estimate the formation of the new pigments.

\subsubsection{Transmission electron microscopy}

Various pigments were examined using (JEOL JX 1230) technique with micro-analyzer electron probe. This technique confirmed the results of the above SEM results besides determining the particle sizes of the prepared pigments.

\subsubsection{X-ray fluorescence}

The different concentrations of each element in the prepared pigments were determined using Axios, sequential WD-XRF spectrometer, PANalytical 2005.

\subsection{Formulation of paints based on alkyd resin}

\subsubsection{Preparation of anticorrosive paint formulations}

The prepared pigments were tested in 15 paint formulations. These paint formulations contain silica fume, commercial titanium dioxide, silica fume covered with different layer thicknesses of titanium dioxide denoted as $\mathrm{SiO}_{2} / \mathrm{TiO}_{2}(1), \mathrm{SiO}_{2} / \mathrm{TiO}_{2}(2)$, and $\mathrm{SiO}_{2} / \mathrm{TiO}_{2}(3)$ expressing concentration of titanium dioxide layers in ascending order from the lower to the higher concentration. All paint formulations were based on medium oil-modified soya-bean dehydrated castor oil alkyd resin. The formulations were divided into three groups; each is based on different P/B ratio (group I has P/B 1.74, group II has P/B 2.175 and group III has $\mathrm{P} / \mathrm{B}$ 3). Paint formulations are given in Tables 5-7, while the physical-mechanical and corrosion properties are represented in Table 8 . The corrosion features of the paint films are shown in Figs. (5-7).

\subsection{The effects of the prepared pigments on the mechanical properties of paints}

Because the aim of this study was to formulate a pigment whose properties would contribute to the improvement of the mechanical and corrosion qualities of the paints, selected physical-chemical and corrosion tests were carried out.

\subsubsection{Determining the resistance of paints against impact (ASTM D 5638-00, 2007)}

The result of this test reveals at what height (in $\mathrm{cm}$ ) of the free fall of a weight onto the paint, the paint film has not yet been disturbed.

\subsubsection{Determination of paint resistance against cupping in Erichsen apparatus (ASTM D 5638-00, 2007)}

The result of this test reveals the cupping of the test panel with a coating in $\mathrm{mm}$ at which the first impairment of the paint occurred. 


\subsubsection{Determination of paint hardness (ASTM D 6577-00, 2007)}

The result of this test indicates the elasticity of paint film by using the simple pendulum test with a needle, when this needle reaches a groove which is made in the paint film, the time it takes in seconds is the measure of the hardness of paint films.

\subsubsection{Determining the degree of coating adhesion by means of a cross-cut test (ASTM D 3359-97, 2007)}

The test was performed with a special cutting knife whose edges are $2 \mathrm{~mm}$ apart. The cut of the created grate was evaluated according to a Gt0-Gt4 scale.

\subsubsection{Overall evaluation of the selected physical-mechanical properties of the paints}

The measured quantities of physical-mechanical nature including the adhesion of the paint film identified by means of a cross-cut test, impact resistance, and resistance against cupping indicate the elasticity, elongation at break, and strength of the paint film. The detected results of the mechanical tests were assigned with the corresponding numerical values from the scale for the determination of physical-mechanical properties. The high value of the different mechanical properties means that the pigment contained in the paint has a positive influence on its mechanical properties.

\subsubsection{The effect of pigment particles on the surface hardness of the paints}

Good surface resistance is important for the resistance of the paints against mechanical impacts, scratches, erosion caused by abrasion of dust particles in the outside atmospheric environment. The determination of the surface hardness of the paint film on glass was carried out by means of a pendulum apparatus, the test consists of measuring the number of oscillations of the pendulum that bears onto the paint film with two steel balls. The unit of measuring of hardness is a percentile value related to the hardness of a glass standard that equals to $100 \%$.

\subsection{The effect of the prepared pigments on the anticorrosion performance and the chemical resistance of the paints}

The primary goal of this study was to prepare a pigment that would increase the anticorrosion performance of the paints. The determination of the properties of the prepared pigments by means of laboratory tests and electrochemical measurements in corrosive environments was a priority assignment.

\subsubsection{Corrosion test evaluation methods}

The evaluation of coatings after exposure to the corrosion tests followed methods based on the (ASTM D 714-87) for degree of blistering, (ASTM D 6294-98) for degree of rusting, and (ASTM D 2803-93) for photographic inspection.

\subsubsection{Electrochemical evaluation method}

Electrochemical impedance spectroscopy (EIS) is an extremely useful technique in generating quantitative data that relates to the quality of the coat on a metal substrate. EIS is 
a very sensitive detector of a coated metal condition, its response can indicate changes in the coating long before any visible damage occurs, and it is not an absolute measurement.

EIS is useful to characterize a painted metal substrate by simultaneously measuring two phenomena: (1) the deterioration of the organic coating caused by exposure to an electrolyte and (2) the increase in corrosion rate of the underlying substrate due to the deterioration of the coating and subsequent attack by the electrolyte.

In EIS, an AC voltage of varying frequency is applied to the sample. It is useful to think of the frequency as a camera shutter that can be very fast (high frequency) for fast reactions and very slow (low frequency) for slow ones. This is the technical feature that allows EIS to gather so much information on an electrochemical reaction in one experiment, and this is why EIS is more useful for coatings than DC electrochemical techniques.

EIS can quantitatively measure both resistances and capacitances in the electrochemical cell. Resistance corresponds to electron transfer reactions such as corrosion, while the capacitance of a metal electrode in contact with an electrolyte is important information for any electrochemical system, for organic coatings, the capacitance measurement is particularly revealing. As the organic coating deteriorates with time during exposure to an electrolyte, EIS can track changes in the capacitance of the coating. The capacitance will change as the coating swells or absorbs water. In addition, changes in the porosity of the coating can be easily measured. EIS can also simultaneously monitor the rate of corrosion of the metallic substrate which generally increases as the protective coating fails, allowing the electrolyte to contact the substrate (Mirabedini et al, 2003; Kendig,et al., 1983; Hernandez et al., 1999; Huang et al., 2008).

In the present work, EIS experiments were carried out using a conventional three-electrode cell. The working electrode was the coated specimen, using a saturated calomel electrode as reference electrode, and a platinum foil $\left(1 \mathrm{~cm}^{2}\right)$ as counter electrode. The used electrolyte was 3.5 wt. \% $\mathrm{NaCl}$ solution. EIS measurements were carried out using AC signals of amplitude $5 \mathrm{mV}$ peak to peak at the open circuit potential in the frequency range between 15 $\mathrm{kHz}$ and $0.3 \mathrm{~Hz}$. EIS data was collected using Gamry PCI300/4 Potentiostat/Galvanostat/Zra analyzer, EIS300 Electrochemical Impedance Spectroscopy software, and Echem Analyst 5.21 for results plotting, graphing, data fitting \& calculating.

\section{Result and discussion}

\subsection{The physical-chemical properties of the prepared pigments}

Silica fume is a fine amorphous kind of silica, while titanium dioxide possess well crystalline particles, since the layers of titanium dioxide were so thin that they do not exceed $10 \%$ of the whole pigment concentration as can be seen in Table (3), they do not alter the crystals of silica and hence the XRD charts do not show any difference between the amorphous structure of uncovered silica fume and the silicas covered with the three concentrations of titanium dioxide. This can be clearly seen in Figure (1).

Figures (2 and 3) show the morphology of the prepared pigments using SEM and TEM. From the featured photos it can be seen that, silica fume possess a spherical particle shapes, while titanium dioxide possess platelet structure. The new pigments possess platelet 

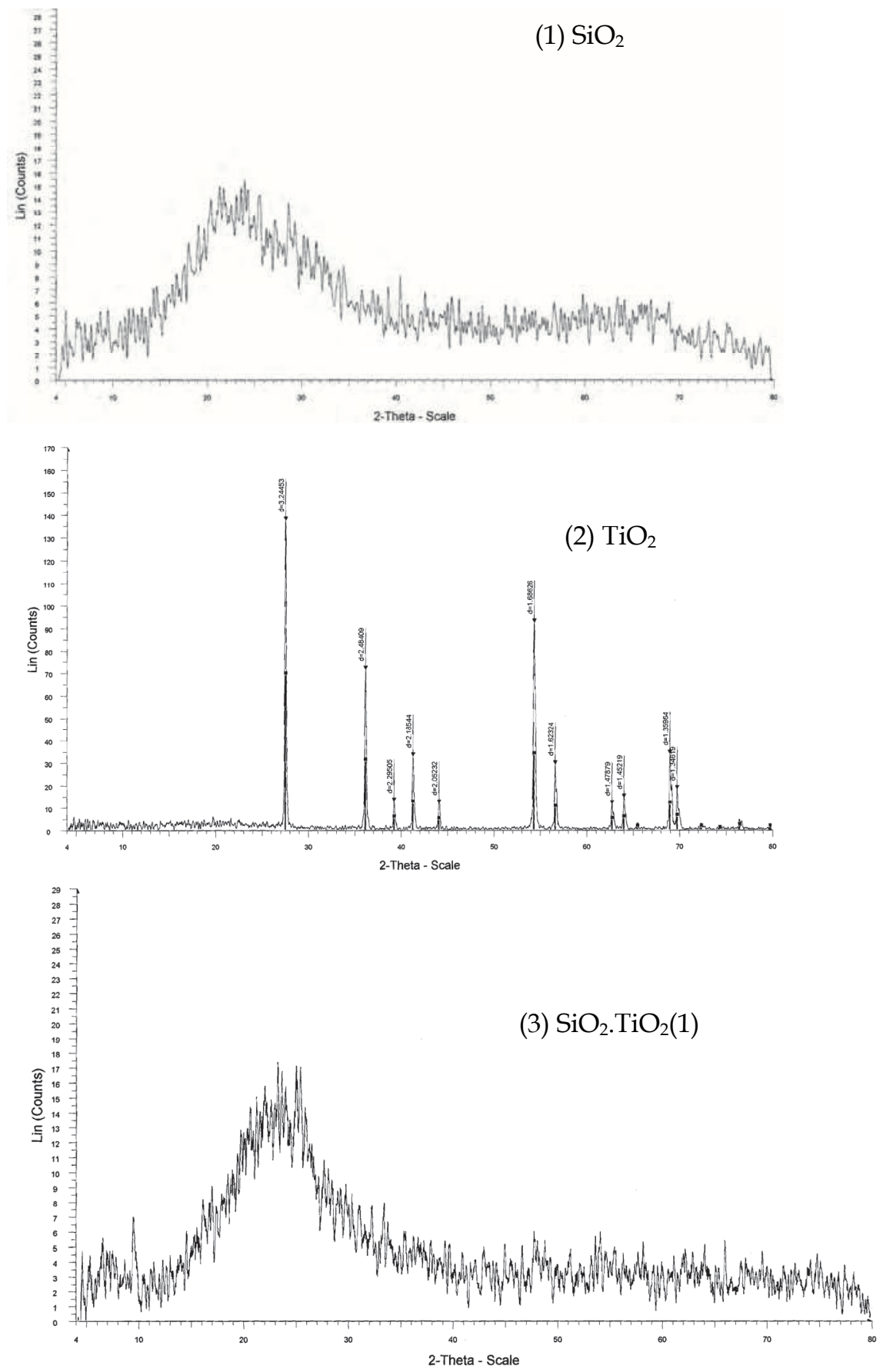

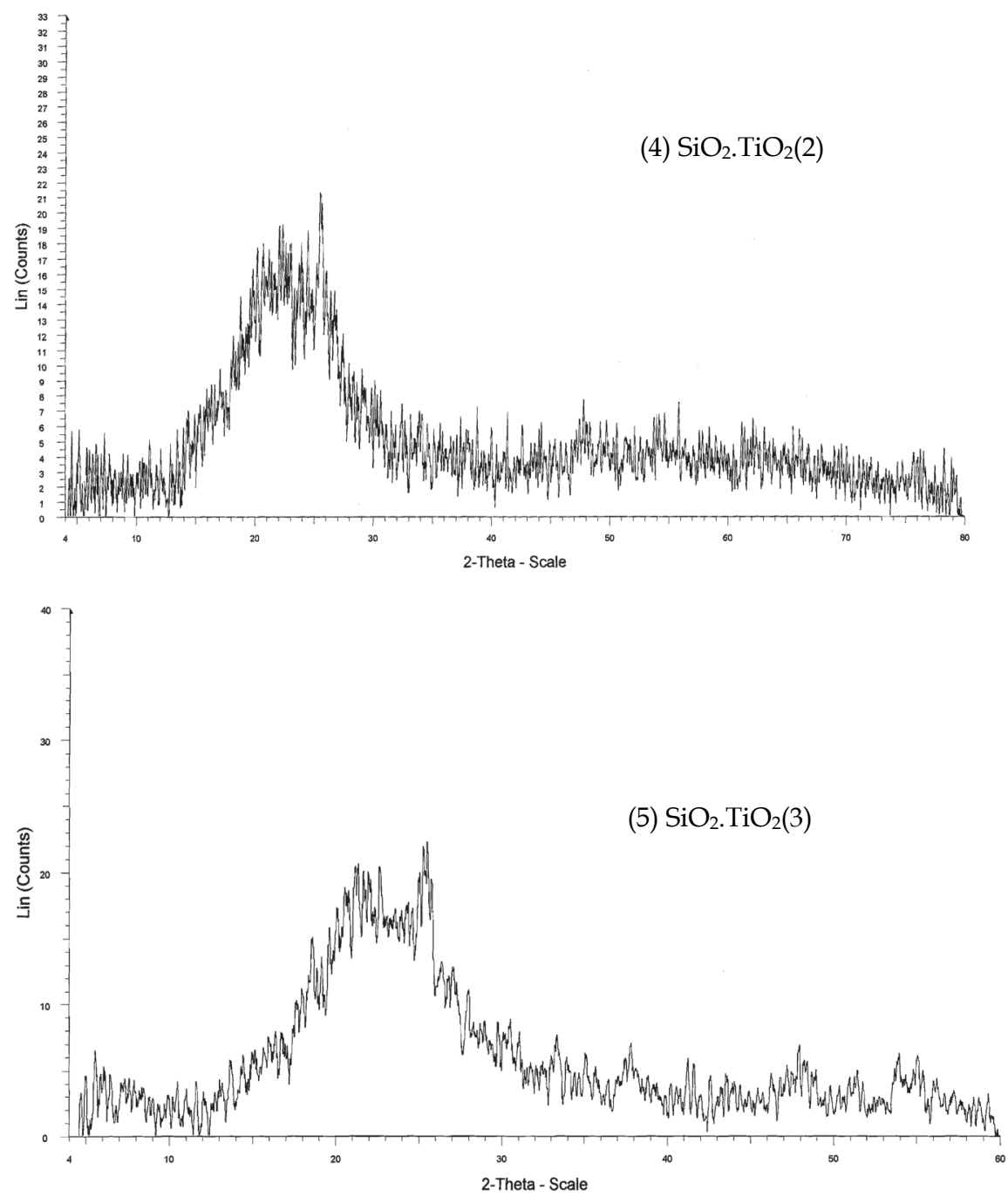

Fig. 1. XRD charts of 1 . silica fume, 2. Titanium dioxide, 3. Silica coated with titanium dioxide (1), 4. Silica coated with titanium dioxide (2), and 5. Silica coated with titanium dioxide (3) 


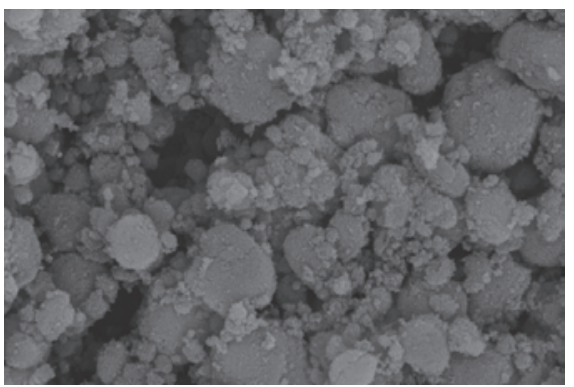

1. Silica fume

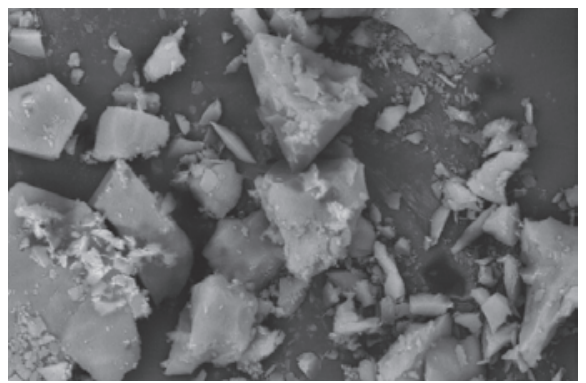

3. Silica covered with $\mathrm{TiO}_{2}(1)$

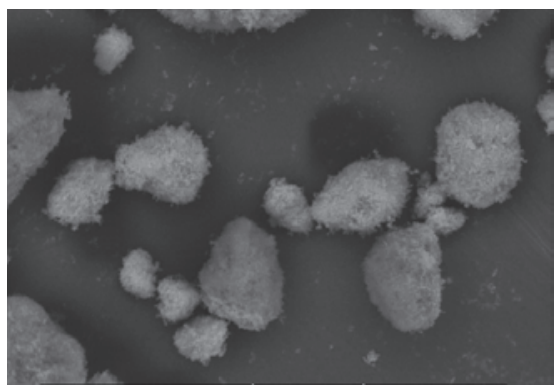

2. Titanium dioxide

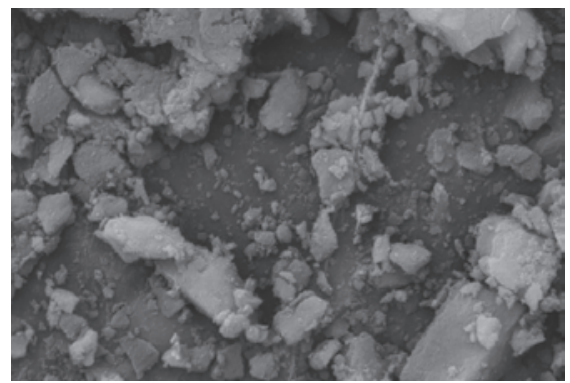

4. Silica covered with $\mathrm{TiO}_{2}(2)$

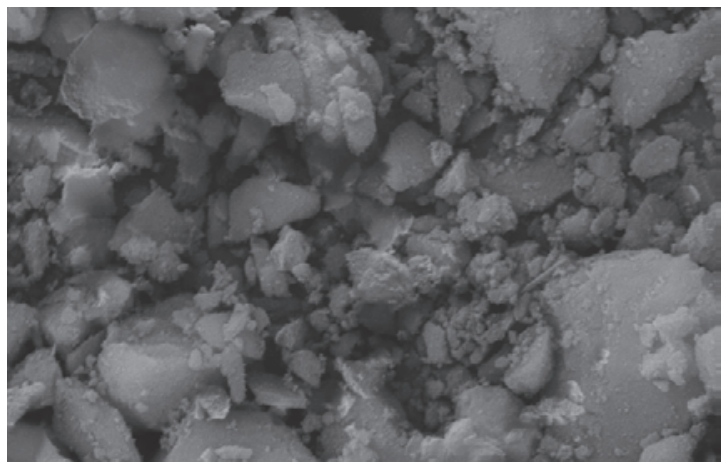

5. Silica covered with $\mathrm{TiO}_{2}$ (3)

Fig. 2. SEM micrographs of 1.Silica, 2.Titanium dioxide, 3, 4 and 5.Silica covered 


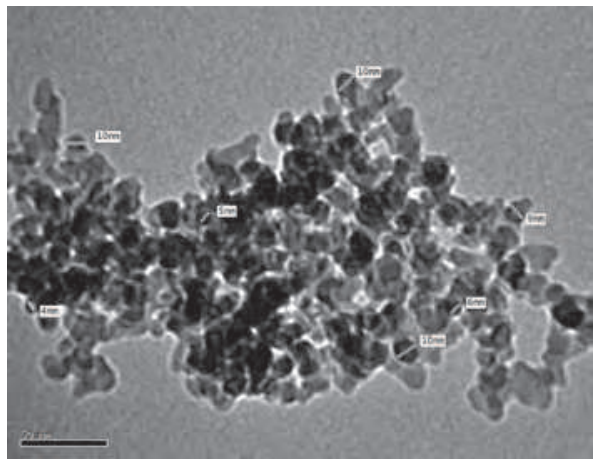

1. Silica fume

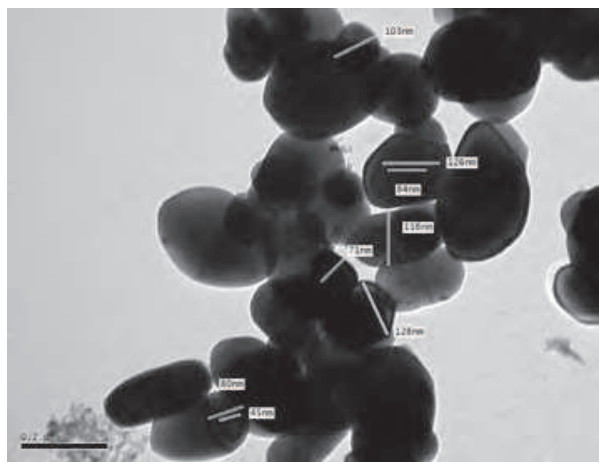

3. Silica covered with $\mathrm{TiO}_{2}(1)$

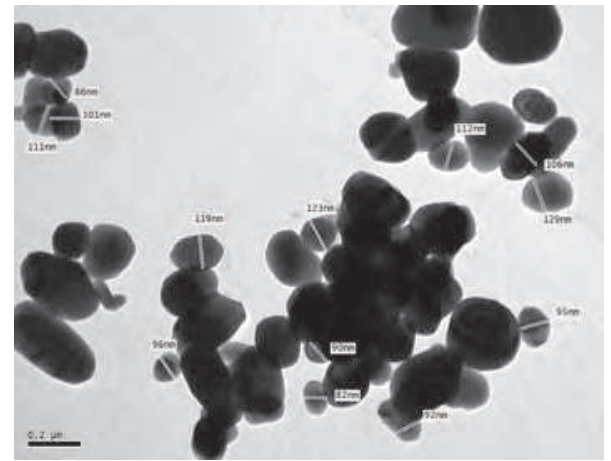

2. Titanium dioxide

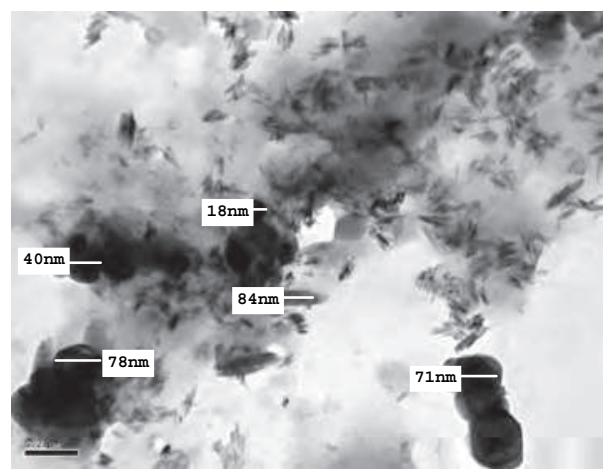

4. Silica covered with $\mathrm{TiO}_{2}(2)$

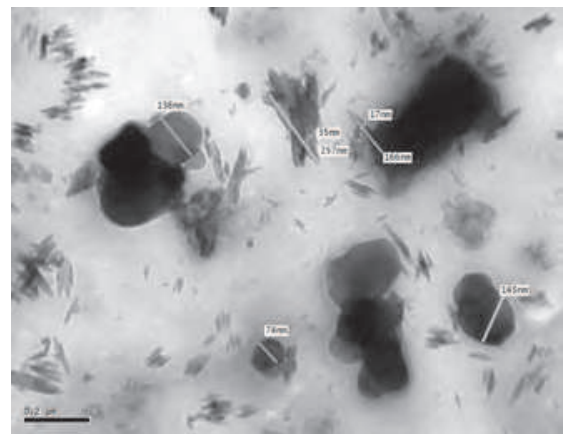

5. Silica covered with $\mathrm{TiO}_{2}(3)$

Fig. 3. TEM micrographs of 1 . Silica, 2. Titanium dioxide, 3, 4 and 5 Silica covered with different concentrations of Titanium dioxide at magnification $120 \mathrm{X}$

structures but of different sizes, this can be obviously seen in the TEM photos shown in Figure (3), where the silica spheres were clearly shown in Figure 3a, while plates of titanium dioxide are shown in figure $3 \mathrm{~b}$, and as the titanium begin to deposit on silica surface, new 
structures begin to appear with the silica appearing as clouds in the background of the photo due to their purity and fine particles with rods or small plates of titanium depositing on its surface with their amounts increasing from Figure $3 \mathrm{~d}$ to Figure $3 \mathrm{e}$. These plates provide a reinforcing effect reducing the water and gas permeability, and therefore imparting good anticorrosive properties and special appearance to the paint film when used in paint formulations (Lambourne, 1987).

Figure (4) shows the EDAX analysis of prepared pigments. EDAX or energy dispersive X-ray analysis can detect the elements on the surface up to one micron depth. As featured from the chart, titanium was detected; this revealed its presence on silica surfaces.

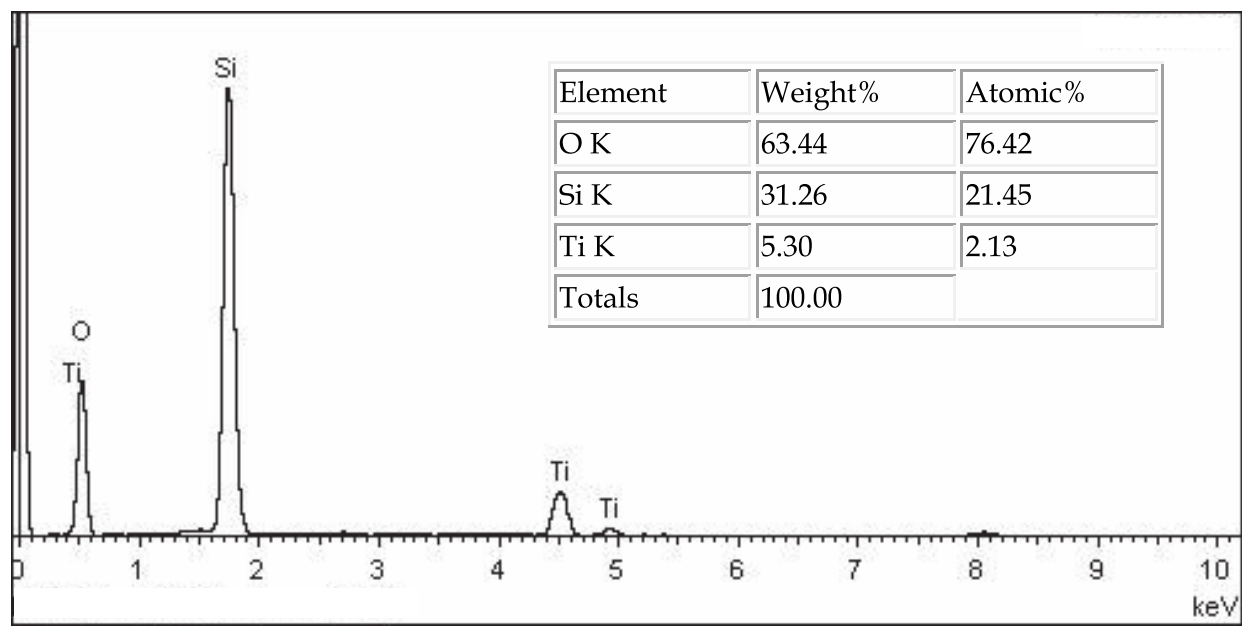

Fig. 4. EDAX analysis of silica fume covered with titanium dioxide

Table 3. represents the XRF analyses results of the three prepared pigments besides the uncovered silica fume. From the Table it can be seen that titanium concentration differs in an ascending order from $\mathrm{SiO}_{2} / \mathrm{TiO}_{2}(1)$ to $\mathrm{SiO}_{2} / \mathrm{TiO}_{2}$ (3), revealing that different concentrations of

\begin{tabular}{|c|c|c|c|c|}
\hline $\begin{array}{c}\text { Concentration of main } \\
\text { constituents (wt. \%) }\end{array}$ & Silica fume & $\mathbf{T i O}_{2} / \mathrm{SiO}_{2} \mathbf{( 1 )}$ & $\mathbf{T i O}_{2} / \mathrm{SiO}_{2}$ (2) & $\mathbf{T i O}_{2} / \mathrm{SiO}_{2}$ (3) \\
\hline $\mathrm{SiO}_{2}$ & 95.54 & 94.48 & 93.61 & 91.78 \\
\hline $\mathrm{TiO}_{2}$ & --- & 2.85 & 3.90 & 5.72 \\
\hline $\mathrm{Al}_{2} \mathbf{O}_{3}$ & 0.34 & 0.36 & 0.37 & 0.35 \\
\hline $\mathrm{Fe}_{2} \mathbf{O}_{3}$ & 0.91 & 1.43 & 1.27 & 1.23 \\
\hline $\mathbf{M g O}$ & 0.70 & 0.60 & 0.60 & 0.57 \\
\hline $\mathbf{C a O}$ & 0.32 & 0.31 & 0.33 & 0.32 \\
\hline $\mathbf{N a}_{2} \mathbf{O}$ & 0.39 & 0.18 & 0.17 & 0.18 \\
\hline $\mathbf{K}_{2} \mathbf{O}$ & 0.80 & 0.95 & 0.98 & 0.86 \\
\hline $\mathbf{P}_{2} \mathbf{O}_{5}$ & 0.07 & 0.06 & 0.06 & 0.06 \\
\hline $\mathbf{S O}_{3}$ & 0.005 & 0.005 & 0.005 & 0.007 \\
\hline $\mathbf{L . O}_{3}$ & 4.93 & 0.62 & 0.53 & 0.76 \\
\hline
\end{tabular}

Table 3. XRF analysis results of the prepared $\mathrm{TiO}_{2} /$ Silica fume pigments Specifications of prepared $\mathrm{SiO}_{2} / \mathrm{TiO}_{2}$ pigment properties 
titanium dioxide is present on surface of silica and these concentrations do not exceed $10 \%$ of the whole pigment concentration.

Specifications of prepared $\mathrm{TiO}_{2} / \mathrm{SiO}_{2}$ pigment properties

From Table (4) it is clear that;

a. Specific gravity of silica was null, it is a very light fluffy powder, but the prepared $\mathrm{TiO}_{2} / \mathrm{SiO}_{2}$ pigments have specific gravity values which are in direct relation with the concentration of titanium dioxide on silica surface.

b. Oil absorption of silica is very high and this is expected because of the silica spherical shapes which allow more oil to be deposited in the voids between the particles to form a paste, but $\mathrm{TiO}_{2} / \mathrm{SiO}_{2}$ pigments have lower oil absorption than silica. As it is well known that oil absorption expresses how much binder can be consumed by the pigment, and thus how this pigment is economically feasible when used in paint formulations. As the oil absorption is higher, more binder will be needed to completely wet the pigment and form a homogeneous paint film.

c. Bulking value (BV) expresses the volume of paint for a given weight of a pigment, therefore pigments with higher bulking values as in silica and $\mathrm{TiO}_{2} / \mathrm{SiO}_{2}$ can be considered more economic.

d. $\mathrm{pH}$ values of the different pigments are neutral.

In general, the new pigments possess better physical properties than either of its components individually. This was obvious from the specific gravity and oil absorption of these core-shell pigments.

\begin{tabular}{|c|c|c|c|c|c|}
\hline Materials & $\begin{array}{c}\text { Oil } \\
\text { absorption } \\
\text { (g/100g) }\end{array}$ & Sp.Gr. & $\begin{array}{c}\text { BV } \\
\text { (gal/100b) }\end{array}$ & pH & $\begin{array}{c}\text { Whiteness } \\
\text { (\%) }\end{array}$ \\
\hline $\mathrm{SiO}_{2}$ & 819.68 & 0 & 0 & 7 & 97 \\
\hline $\mathrm{TiO}_{2}$ & 22 & 4.24 & 2.842 & 7 & 95 \\
\hline $\mathrm{TiO}_{2} / \mathrm{SiO}_{2}(1)$ & 221.84 & 1.59 & 7.578 & 7 & 97 \\
\hline $\mathrm{TiO}_{2} / \mathrm{SiO}_{2}(2)$ & 193.64 & 1.53 & 7.875 & 7 & 98 \\
\hline $\mathrm{TiO}_{2} / \mathrm{SiO}_{2}(3)$ & 189.88 & 1.78 & 6.770 & 7 & 98 \\
\hline
\end{tabular}

Table 4. Characteristics of prepared titanium dioxide/kaolin pigments

\subsection{The effect of prepared pigments on mechanical properties of paints}

Tables (5-7) represent the paint formulations, while Table (8) expresses the results of determining hardness of organic coatings by means of pendulum apparatus; also impact and ductility were determined. Paint films containing silica show the best mechanical properties among the group, while those containing titanium dioxide show the lowest values, this is may be due to the spherical particles of silica which gives the film elasticity due to the voids present between these spheres. This can be in accordance with the properties of silica which are almost in the nano-scale and paint films containing nanopigments have the following properties; 


\begin{tabular}{|c|c|c|c|c|c|}
\hline Constituent (\%wt.) & $\mathbf{1}$ & $\mathbf{2}$ & $\mathbf{3}$ & $\mathbf{4}$ & $\mathbf{5}$ \\
\hline $\mathrm{Fe}_{2} \mathrm{O}_{3}$ (Hematite) & 10 & 10 & 10 & 10 & 10 \\
\hline Kaolin & 15 & 15 & 15 & 15 & 15 \\
\hline $\mathrm{ZnO}$ & 7 & 7 & 7 & 7 & 7 \\
\hline $\mathrm{SiO}_{2}$ & 30 & --- & --- & --- & --- \\
\hline $\mathrm{TiO}_{2}$ & --- & 30 & --- & --- & --- \\
\hline $\mathrm{TiO}_{2} / \mathrm{SiO}_{2}$ (1) & --- & --- & 30 & --- & --- \\
\hline $\mathrm{TiO}_{2} / \mathrm{SiO}_{2}$ (2) & --- & --- & --- & 30 & --- \\
\hline $\mathrm{TiO}_{2} / \mathrm{SiO}_{2}$ (3) & --- & --- & --- & --- & 30 \\
\hline $\mathrm{Total}_{\text {pigment }}$ & 63.5 & 63.5 & 63.5 & 63.5 & 63.5 \\
\hline Total binder & 36.5 & 36.5 & 36.5 & 36.5 & 36.5 \\
\hline P/B & 1.74 & 1.74 & 1.74 & 1.74 & 1.74 \\
\hline Wetting \& dispersing agent & 1 & 1 & 1 & 1 & 1 \\
\hline Drier & 0.5 & 0.5 & 0.5 & 0.5 & 0.5 \\
\hline Total & 100 & 100 & 100 & 100 & 100 \\
\hline
\end{tabular}

Table 5. Paint formulations of $\mathrm{TiO}_{2} / \mathrm{SiO}_{2}$ pigments with medium oil alkyd resin (Group I)

\begin{tabular}{|c|c|c|c|c|c|}
\hline Constituent (\%wt.) & $\mathbf{6}$ & $\mathbf{7}$ & $\mathbf{8}$ & $\mathbf{9}$ & $\mathbf{1 0}$ \\
\hline $\mathbf{F e}_{2} \mathbf{O}_{3}$ (Hematite) & 15 & 15 & 15 & 15 & 15 \\
\hline Kaolin & 15 & 15 & 15 & 15 & 15 \\
\hline $\mathrm{ZnO}$ & 7 & 7 & 7 & 7 & 7 \\
\hline $\mathrm{SiO}_{2}$ & 30 & --- & --- & --- & --- \\
\hline $\mathrm{TiO}_{2}$ & --- & 30 & --- & --- & --- \\
\hline $\mathrm{TiO}_{2} / \mathrm{SiO}_{2}$ (1) & --- & --- & 30 & --- & --- \\
\hline $\mathrm{TiO}_{2} / \mathrm{SiO}_{2}$ (2) & --- & --- & --- & 30 & --- \\
\hline $\mathrm{TiO}_{2} / \mathrm{SiO}_{2}$ (3) & --- & --- & --- & --- & 30 \\
\hline $\mathrm{Total}_{\mathbf{p i g m e n t}}$ & 68.5 & 68.5 & 68.5 & 68.5 & 68.5 \\
\hline $\mathrm{Total}_{\text {binder }}$ & 31.5 & 31.5 & 31.5 & 31.5 & 31.5 \\
\hline P/B & 2.175 & 2.175 & 2.175 & 2.175 & 2.175 \\
\hline Wetting \& dispersing agent & 1 & 1 & 1 & 1 & 1 \\
\hline Drier & 0.5 & 0.5 & 0.5 & 0.5 & 0.5 \\
\hline Total & 100 & 100 & 100 & 100 & 100 \\
\hline
\end{tabular}

Table 6. Paint formulations of $\mathrm{TiO}_{2} / \mathrm{SiO}_{2}$ pigments with medium oil alkyd resin (Group II)

According to (Guin et al., 2011; Otterstedt \& Brandreth, 1998; Salamone, 1999), the main advantages of nano-coating or coatings containing nano-pigments are:

- Better surface appearance.

- Good chemical resistance.

- Decrease in permeability to corrosive environment and hence better corrosion properties.

- Optical clarity.

- Increase in modulus and thermal stability. 
- $\quad$ Easy to clean surface.

- Anti-skid, anti-fogging, anti-fouling and anti-graffiti properties.

- Better thermal and electrical conductivity.

- Better retention of gloss and other mechanical properties like scratch resistance.

- Anti-reflective in nature

- Chromate and lead free

- Good adherence on different type of materials.

In general, $\mathrm{TiO}_{2} / \mathrm{SiO}_{2}$ pigments show less mechanical properties than silica, but better than paint films containing titanium dioxide and this is due to that as titanium dioxide layers precipitated on silica surface transfers the particle sizes to the micron-scale and also they disturb the texture of silica by altering their platelet particles between the silica spheres leading to less homogenous texture and thus less mechanical properties. Paint films containing titanium dioxide exhibit poor mechanical properties.

\begin{tabular}{|c|c|c|c|c|c|}
\hline Constituent (\%wt.) & $\mathbf{1 1}$ & $\mathbf{1 2}$ & $\mathbf{1 3}$ & $\mathbf{1 4}$ & $\mathbf{1 5}$ \\
\hline $\mathrm{Fe}_{\mathbf{2}} \mathbf{O}_{3}$ (Hematite) & 21.5 & 21.5 & 21.5 & 21.5 & 21.5 \\
\hline Kaolin & 15 & 15 & 15 & 15 & 15 \\
\hline $\mathrm{ZnO}$ & 7 & 7 & 7 & 7 & 7 \\
\hline $\mathrm{SiO}_{2}$ & 30 & --- & --- & --- & --- \\
\hline $\mathrm{TiO}_{2}$ & --- & 30 & --- & --- & --- \\
\hline $\mathrm{TiO}_{2} / \mathrm{SiO}_{2}$ (1) & --- & --- & 30 & --- & --- \\
\hline $\mathrm{TiO}_{2} / \mathrm{SiO}_{2}$ (2) & --- & --- & --- & 30 & --- \\
\hline $\mathrm{TiO}_{2} / \mathbf{S i O}_{2}$ (3) & --- & --- & --- & --- & 30 \\
\hline $\mathrm{Total}_{\text {pigment }}$ & 75 & 75 & 75 & 75 & 75 \\
\hline $\mathrm{Total}_{\text {binder }}$ & 25 & 25 & 25 & 25 & 25 \\
\hline $\mathbf{P} / \mathbf{B}$ & 3 & 3 & 3 & 3 & 3 \\
\hline Wetting \& dispersing agent & 1 & 1 & 1 & 1 & 1 \\
\hline Drier & 0.5 & 0.5 & 0.5 & 0.5 & 0.5 \\
\hline Total & 100 & 100 & 100 & 100 & 100 \\
\hline
\end{tabular}

Table 7. Paint formulations of $\mathrm{TiO}_{2} / \mathrm{SiO}_{2}$ pigments with medium oil alkyd resin (Group III)

\subsection{The effect of prepared pigments on anticorrosive properties of paints}

Table (8) features the results of determining the anticorrosion performance of paint films through blistering on paint surface and rust under film. The method classifies the osmotic blisters to the groups according to their sizes designated by numbers $2,4,6$, and 8 (2 denotes the largest size, 8 the smallest one).

To the blister size information on the frequency of occurrence is given. The highest occurrence density of blisters is designated as D (dense), the lower ones as MD (medium dense), $\mathrm{M}$ (medium) and $\mathrm{F}$ (few). In such away a series from the surface area attacked at least by the osmotic blisters up to the heaviest occurrence can be formed as follows: 8F-6F4F-2F-8M-6M-4M-2M-8MD-6MD-4MD-2MD-8D-6D-4D-2D. 


\begin{tabular}{|c|c|c|c|c|c|}
\hline \multicolumn{6}{|c|}{ Group I } \\
\hline Drying time, $h r$. & 1 & 2 & 3 & 4 & 5 \\
\hline Surface dry & \multicolumn{5}{|c|}{$-1-2-$} \\
\hline Thorough dry & \multicolumn{5}{|c|}{$\longrightarrow 3-4 \longrightarrow$} \\
\hline Adhesion & Gt0 & Gt0 & Gt0 & Gt0 & Gt0 \\
\hline Hardness, Sec $(90 \mu)$ & 60 & 67 & 74 & 72 & 73 \\
\hline Ductility, $M m$ & 6.3 & 3 & 5.3 & 5.1 & 5.1 \\
\hline Impact resistance, $K g . m$. & 0.75 & 0.325 & 0.6 & 0.563 & 0.525 \\
\hline \multicolumn{6}{|c|}{ Corrosion resistance } \\
\hline Degree of Blistering & 10 & $6 \mathrm{M}$ & 10 & 10 & 10 \\
\hline Degree of rusting & $8-\mathrm{G}$ & $7-S$ & 7-P & $6-G$ & $5-\mathrm{G}$ \\
\hline Filiform corrosion & \multicolumn{5}{|c|}{$\longrightarrow$ Fig.1-FA- } \\
\hline \multicolumn{6}{|c|}{ Group II } \\
\hline Drying time, $h r$. & 6 & 7 & 8 & 9 & 10 \\
\hline Surface dry & \multicolumn{5}{|c|}{$\longrightarrow$ - $1-2 \longleftarrow$} \\
\hline Thorough dry & \multicolumn{5}{|c|}{$\longrightarrow$ 3-4 } \\
\hline Adhesion & Gt1 & Gt0 & Gt1 & Gt1 & Gt1 \\
\hline Hardness, Sec $(90 \mu)$ & 72 & 73 & 78 & 80 & 82 \\
\hline Ductility, $M m$ & 6.7 & 2.7 & 5.8 & 5.5 & 5.4 \\
\hline Impact resistance, $\mathrm{Kg} . \mathrm{m}$. & 0.738 & 0.275 & 0.55 & 0.488 & 0.45 \\
\hline \multicolumn{6}{|c|}{ Corrosion resistance } \\
\hline Degree of Blistering & $4 \mathrm{MD}$ & $8 \mathrm{M}$ & $8 \mathrm{~F}$ & 10 & $4 \mathrm{MD}$ \\
\hline Degree of rusting & $5-\mathrm{G}$ & 10 & 7-P & 10 & $5 \mathrm{G}$ \\
\hline Filiform corrosion & \multicolumn{5}{|c|}{ Fig.1-FA- } \\
\hline \multicolumn{6}{|c|}{ Group III } \\
\hline Drying time, $h r$. & 11 & 12 & 13 & 14 & 15 \\
\hline Surface dry & \multicolumn{5}{|c|}{$\longrightarrow$ - $1-2 \longleftarrow$} \\
\hline Thorough dry & \multicolumn{5}{|c|}{$\longrightarrow-4 \longrightarrow$} \\
\hline Adhesion & Gt1 & Gt0 & Gt1 & Gt1 & Gt1 \\
\hline Hardness, Sec $(90 \mu)$ & 78 & 82 & 88 & 92 & 92 \\
\hline Ductility, $M m$ & 6.4 & 4.3 & 5.2 & 5.2 & 5.0 \\
\hline Impact resistance, $\mathrm{Kg} . \mathrm{m}$. & 0.738 & 0.263 & 0.525 & 0.488 & 0.425 \\
\hline \multicolumn{6}{|c|}{ Corrosion resistance } \\
\hline Degree of Blistering & $4 \mathrm{MD}$ & $4 \mathrm{M}$ & $6 \mathrm{M}$ & $6 \mathrm{MD}$ & $4 \mathrm{MD}$ \\
\hline Degree of rusting & $7-S$ & 10 & $8-\mathrm{P}$ & $6-S$ & $4-S$ \\
\hline Filiform corrosion & \multicolumn{5}{|c|}{ Fig.1-FA- } \\
\hline
\end{tabular}

8-G, $0.1 \%$ general rusting; 7-S, $0.3 \%$ spot rusting; $7-\mathrm{P}, 0.3 \%$ pinpoint rusting; $6-\mathrm{G}, 1 \%$ general rusting; 5 G, 3\% general rusting; $8-\mathrm{P}, 0.1 \%$ pinpoint rusting, 6-S, $1 \%$ spot rusting, and $4-\mathrm{S}, 10 \%$ spot rusting.

Table 8. Physico-mechanical and corrosion characteristics of dry paint films

As can be detected from Tables (5-8) and Figures (5-7), that paint films of group II were better in their performance than the other groups in the rust under paint films revealing that the P/B 2.175 is better than the other $\mathrm{P} / \mathrm{B}$ ratios. Also paint films containing $\mathrm{SiO}_{2} / \mathrm{TiO}_{2}(1)$ and $\mathrm{SiO}_{2} / \mathrm{TiO}_{2}(2)$ were better in their performance than $\mathrm{SiO}_{2} / \mathrm{TiO}_{2}(3)$, this may be due to 
1. $\mathrm{SiO}_{2}$

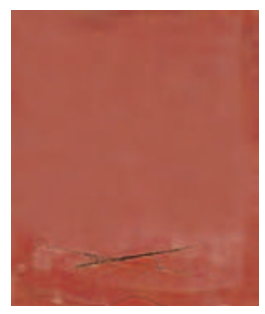

3. $\mathrm{TiO}_{2} / \mathrm{SiO}_{2}(1)$

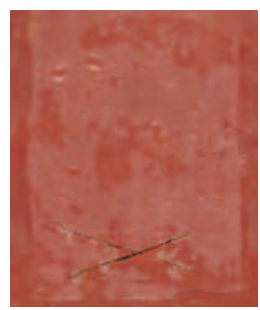

4. $\mathrm{TiO}_{2} / \mathrm{SiO}_{2}(2)$

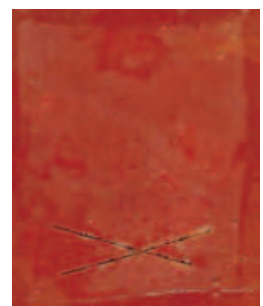

2. $\mathrm{TiO}_{2}$

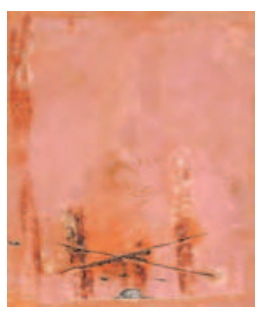

5. $\mathrm{TiO}_{2} / \mathrm{SiO}_{2}(3)$

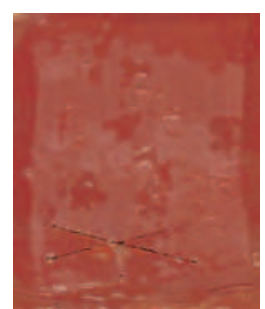

Fig. 5. Photos of paint films of group I after immersion in $3.5 \% \mathrm{NaCl}$ after 28 days

6. $\mathrm{SiO}_{2}$

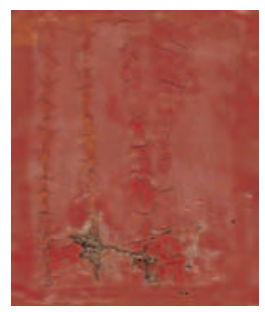

8. $\mathrm{TiO}_{2} / \mathrm{SiO}_{2}(1)$

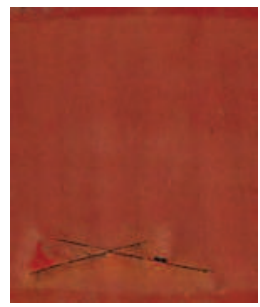

7. $\mathrm{TiO}_{2}$

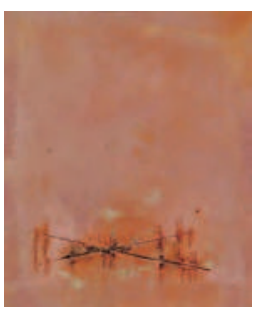

10. $\mathrm{TiO}_{2} / \mathrm{SiO}_{2}(3)$

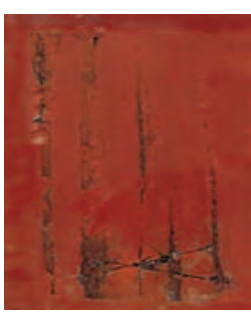

Fig. 6. Photos of paint films of group II after immersion in $3.5 \% \mathrm{NaCl}$ after 28 days 
11. $\mathrm{SiO}_{2}$

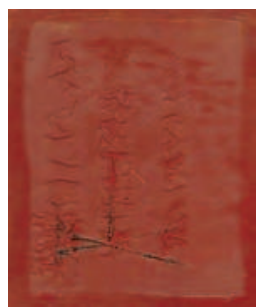

13. $\mathrm{TiO}_{2} / \mathrm{SiO}_{2}(1)$

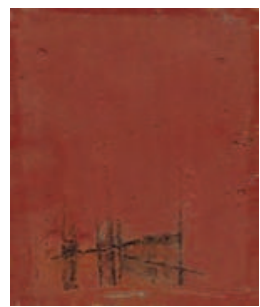

12. $\mathrm{TiO}_{2}$

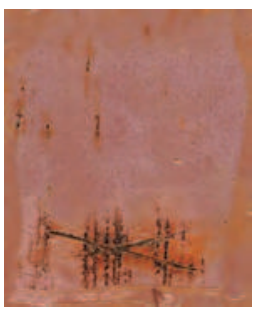

15. $\mathrm{TiO}_{2} / \mathrm{SiO}_{2}(3)$

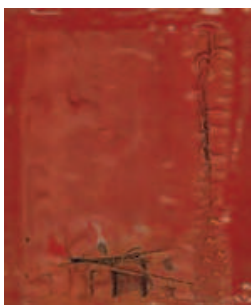

Fig. 7. Photos of paint films of group III after immersion in $3.5 \% \mathrm{NaCl}$ after 28 days

the photocatalytic effect of titanium dioxide on the surface of silica which is in accordance with its concentration, i.e. as titanium dioxide concentration increases, the photocatalytic effect also increases. This behavior can be also explained according to that as concentration of titanium increases, it alters the silica particles causing random effect between the particles and hence less film compactness leading to easiness of the passage of corroding materials to the metal substrate.

\subsection{Electrochemical studies on paint films}

EIS was employed to investigate the corrosion protection performance $\mathrm{TiO}_{2} / \mathrm{SiO}_{2}$ core-shell pigments in anticorrosive paint formulations based on different $\mathrm{P} / \mathrm{B}$ ratios on the protection of mild steel substrate in $3.5 \mathrm{wt} \% \mathrm{NaCl}$ at different immersion times. The results of the analysis and calculations of the impedance data, at different immersion times 1, 7, 14, 21 and 28 days, were listed in Table 9.

Inspections of this data indicate the following;

a. The coating resistance $(R c)$ is clearly higher in case of group II (P/B 2.175) paint formulations than that of other groups at all immersion times. It is obvious that the rate of corrosion decrease in the order: group II > group I > group III.

b. The coating resistance $(R c)$ of paint films containing $\mathrm{TiO}_{2} / \mathrm{SiO}_{2}(1)$ and $\mathrm{TiO}_{2} / \mathrm{SiO}_{2}(2)$ were better in their performance than $\mathrm{SiO}_{2} / \mathrm{TiO}_{2}(3)$.

c. As shown in Figure 5, the paint film containing $\mathrm{TiO}_{2} / \mathrm{SiO}_{2}(1)$ in group II (paint no. 8) offered a very good resistance even after 28 days immersion in $3.5 \mathrm{wt} \% \mathrm{NaCl}$ solution $\left(9.809 \mathrm{~K}\right.$ ohm), indicating that paint formulations containing $\mathrm{TiO}_{2} / \mathrm{SiO}_{2}$ (1) in $\mathrm{P} / \mathrm{B} 2.175$ 
is the best among the three groups and they can provide effective protection to carbon steel.

d. The coating resistance $(R c)$ is inversely proportional to immersion times. As paint no. 8 was the best among the groups it was taken as an example to show in Figure 5 the typical Nyquist plots after different immersion time in $3.5 \mathrm{wt} \% \mathrm{NaCl}$.

\begin{tabular}{lllrrrrr}
\hline \multirow{2}{*}{ Group } & \multirow{2}{*}{ No. } & Sample & \multicolumn{2}{c}{$R_{c}\left(\mathrm{Kohm} . \mathrm{cm}^{2}\right)$} \\
\cline { 4 - 8 } & & \multicolumn{1}{l}{ d day } & 7 day & 14 day & 21 day & 28 day \\
\hline $\mathrm{I}$ & 1 & $\mathrm{SiO}_{2}$ & 2.197 & 1.114 & 0.692 & 0.541 & 0.474 \\
& 3 & $\mathrm{TiO}_{2} / \mathrm{SiO}_{2}(1)$ & 3.271 & 2.845 & 2.696 & 2.388 & 1.174 \\
& 4 & $\mathrm{TiO}_{2} / \mathrm{SiO}_{2}(2)$ & 3.923 & 0.604 & 0.430 & 0.374 & 0.265 \\
& 5 & $\mathrm{TiO}_{2} / \mathrm{SiO}_{2}(3)$ & 1.038 & 0.764 & 0.681 & 623.7 & 0.503 \\
$\mathrm{II}$ & 6 & $\mathrm{SiO}_{2}$ & 0.933 & 0.660 & 0.658 & 0.372 & 0.271 \\
& 8 & $\mathrm{TiO}_{2} / \mathrm{SiO}_{2}(1)$ & 147.34 & 25.36 & 13.09 & 11.63 & 9.809 \\
& 9 & $\mathrm{TiO}_{2} / \mathrm{SiO}_{2}(2)$ & 62.67 & 9.896 & 5.693 & 4.012 & 3.033 \\
& 10 & $\mathrm{TiO}_{2} / \mathrm{SiO}_{2}(3)$ & 2.015 & 1.192 & 0.790 & 0.564 & 0.486 \\
& 11 & $\mathrm{SiO}_{2}$ & 0.145 & 0.135 & 0.109 & 0.082 & 0.042 \\
& 13 & $\mathrm{TiO}_{2} / \mathrm{SiO}_{2}(1)$ & 1.158 & 0.700 & 0.598 & 0.401 & 0.355 \\
& 14 & $\mathrm{TiO}_{2} / \mathrm{SiO}_{2}(2)$ & 1.021 & 0.513 & 0.489 & 0.388 & 0.329 \\
& 15 & $\mathrm{TiO}_{2} / \mathrm{SiO}_{2}(3)$ & 0.331 & 0.105 & 0.079 & 0.060 & 0.056 \\
\hline
\end{tabular}

Table 9. EIS results for different paint formulations in $3.5 \mathrm{wt} \% \mathrm{NaCl}$ at different immersion times

From the Figure it can be detected that the decrease in coating resistance may be due to the penetration of water and movement of ionic species among the coating layer, increasing the coating conductivity. This can be explained according to the following steps;

- Initially, the electrolyte penetrates through the coating layer, and sets up conducting paths at different depths within the coating (Xianming et al., 2009). With increase immersion time, the electrochemical reactions at the interface between the coating and the metal surface make progress where the electrolyte phase meets the metal/oxide interface and a corrosion cell is then activated.

- This step is Followed by that the barrier properties of the coating are decreased, suggesting a decrease in the coating resistance, i.e. decrease the radius of the semi-circle (Del Amo et al., 1999).

Generally, electrochemical studies were in high accordance with accelerated laboratory test results.

\subsubsection{Some suggested mechanisms of protection concerning the new prepared pigments}

- Silica is used in coatings and paints to increase the scratch resistance. The silica fine particles do not interfere with the visible light, only by a high quality of dispersion, 
cloudiness can be avoided and transparency can be achieved. The high tendency of silica particles to agglomerate with each other makes it difficult to assure that every single silica particle can react with the surrounding medium. The reaction of the individual particles with the medium is important for many applications in order to achieve the desired results (Kirubaharan et al., 2009).

- Hydrophobic silica fume is used to enhance water and corrosion resistance this is due to improved pigment stabilization in the coating system combined with the stronger barrier effect inherent to hydrophobic silica fume. This barrier effect in particular is what prevents moisture from penetrating the coating film and reaching the substrate (Guin et al., 2011).

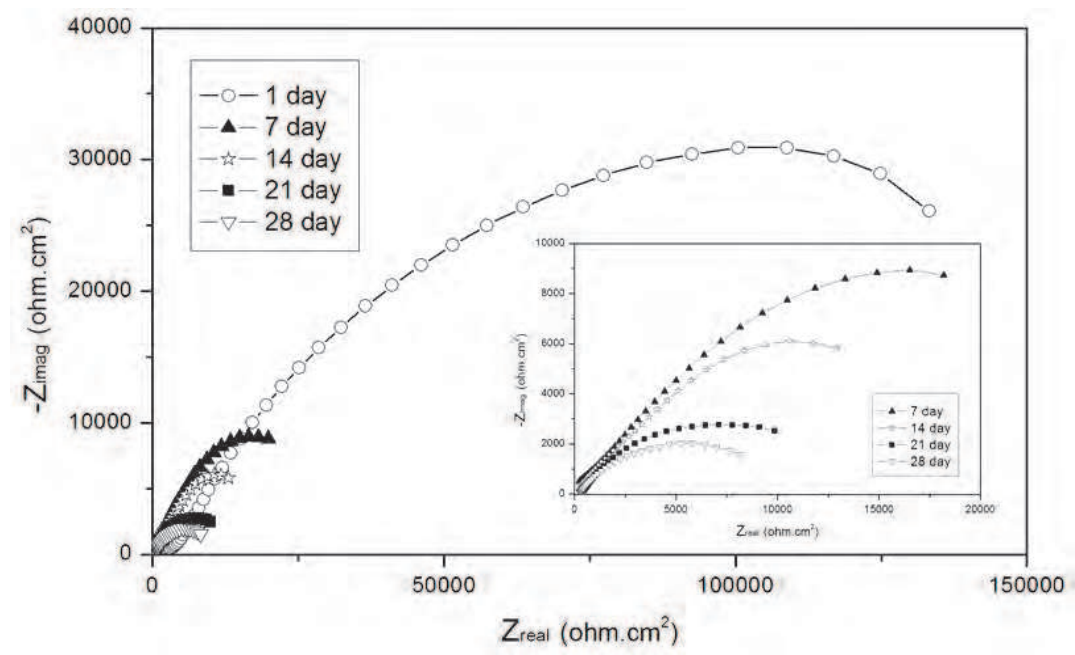

Fig. 9. Nyquist plots for $\mathrm{TiO}_{2} / \mathrm{SiO}_{2}$ (1) of group II (paint no. 8) in $3.5 \mathrm{wt} \% \mathrm{NaCl}$ at different immersion times $1,7,14,21$ and 28 days

- Fine Silica fume is used as additive that enhance the surface smoothness and dispersability of the media into which they are added. Their fine silica particles have a lower coefficient of friction than titanium dioxide and other popular fillers. On a molecular level, these particles are perfectly spherical in shape and move more freely to provide a superior tactile feel which serve as a matting agent for paints besides being corrosion resistant (Kirubaharan et al., 2009).

- Durability is an important property of titanium dioxide, and since it is present in only very low concentrations in the prepared pigments, its opacity is controlled, but in spite of this it help in increasing the hiding power and durability of the new prepared pigments (Salamone 1999; Patton 1973; Ahmed \& Selim, 2010).

- Titanium dioxide can also contribute to some extent to the preservation of the physical integrity of the medium in which it is dispersed by providing protection against cracking, checking, loss of adhesion and loss of tensile strength (Ahmed \& Selim 2010; Ahmed \& Selim, 2011).

- Titanium dioxide particles forming the shell were arranged in alignment between the silica particles comprising the core. In case of low concentration of titanium dioxide, its 
small platelet particles order themselves in between the voids of the spherical silica particles in a close-pack texture locking the voids between silica particles and thus more compact paint film will be formed, prohibiting the formation of blisters or rust under film. As the concentration of titanium dioxide increases, a less compact film will be formed and a disturbance between silica particles occurs, these spaces formed between the binder and the pigment particles, even under the best circumstances give the chance for areas arise on the surface of the pigment particle where the binder and the particle may be in extremely close physical proximity but are not chemically bonded. This area between binder and pigment can be a potential route for water molecules to slip through the cured film (Forsgren, 2006, Ahmed \& Selim, 2011).

- Titanium dioxide is an inert oxide which imparts barrier properties to organic coatings by impeding the transport of aggressive species to the surface of the substrate. Such pigments orientate themselves parallel to the substrate surface and protect the substrate by providing a tortuous path of diffusion to the substrate. In addition, they may have a reinforcing effect on the mechanical properties of the coating. Its platy particles may be one reason of its protection properties; also it gives excellent hiding power to the films. Titanium dioxide is of high cost and its presence in high concentration may lead to the degradation of paint films due to its photochemical reactivity (Sorensen, 2009, Forsgren, 2006; Ahmed \& Selim, 2010; Ahmed \& Selim, 2011).

- As concentration of titanium dioxide is low, there is no chance for its photochemical reactivity to show itself (Bremmell \& Mensah, 2005).

\section{Conclusions}

1. New pigments based on core-shell method were prepared in this work; these pigments are based on silica fume that is an industrial byproduct which was covered with different concentrations of titanium dioxide.

2. The pigments overcome the low hiding power of silica fume, and the new pigments possess better hiding power that was directly related to the titanium dioxide concentration on the silica surface.

3. The corrosion protection performance was inversely related to the concentration of titanium dioxide, this was because its platy particles alters the spherical silica particles leading to disturbing the texture that leads to less homogenous film and thus less protection.

4. The best corrosion performance among the pigments was $\mathrm{TiO}_{2} / \mathrm{SiO}_{2}$ (1) and the best among the groups was group II with P.B 2.175.

5. Electrochemical studies were in high agreement with the accelerated laboratory test.

\section{Acknowledgment}

This work was supported by Science and Technology Development Fund (STDF) under project number 1242 .

\section{References}

Abu-Ayana, Y.M., Yossef, E.A.M. and El-Sawy, S.M. (2005). Silica fume - formed during the manufacture of ferrosilicon alloys - as an extender pigment in anticorrosive paints, Anti-Corrosion Methods and Materials Vol. 52, No. 3, pp.345 - 352. 
Ahmed, N.M. and Selim, M.M. (2010). Anticorrosive performance of titanium dioxide-talc hybrid pigments in alkyd paint formulations for protection of steel structures, Anticorrosion Methods and Materials Vol. 57, No. 1, pp. 133-141.

Ahmed, N.M. and Selim, M.M. (2011). Innovative titanium dioxide-kaolin mixed pigments performance in anticorrosive paints, Pigment and Resin Technology Vol. 40, No. 1, pp. 4-16.

Barnett, J.R., Miller, S., and Pearce E. (2006). Colour and art: A brief history of pigments. Optics \& Laser Technology Vol. 38, No. 1, pp. 445-453.

Bremmell, K.E. and Mensah, K.E. (2005). Interfacial chemistry mediated behavior of colloidal talc dispersions, J. of Colloid E Interface Sci. Vol. 283, No. 1, pp. 385-391.

Brock, T. (2000). European Coatings Handbook, p. 157, Elsevier.

Brock, T. Groteklaes, M. and Mischke, P. (2000). European coatings handbook, p. 45, Elsevier.

Buxbaum, G. and Pfaff, G. 2005. Industrial inorganic pigments, Chap. 2, p.201, Wiley interscience, N.Y.

Degryse, P. Elsen, J. (2003). Industrial minerals: resources, characteristics, and applications, pp. 320-323, Leuvin University Press, Netherlands.

Del Amo, B. Romagnoli, R. Deya, C. and Gonzalez, J.A. (2002). High performance waterbased paints with non-toxic anticorrosive pigments, Progress in Organic Coatings Vol. 45, No. 3, pp. 389-397.

Del Amo, B. Romagnoli, R. and Vetere, V.F. (1999). Steel Corrosion Protection by Means of Alkyd Paints Pigmented with Calcium Acid Phosphate, Ind. Eng. Chem. Res. Vol. 38, No. 3, pp. 2310-2314.

Forsgren, A. (2006). Corrosion Control through Organic Coatings, (Chap. 2), pp. 37-39, Taylor \& Francis.

Gaumet, S. Siampigingue, N. Lemaire, J. and Pacaud, B. (1997). Influence of titanium dioxide pigment characteristics on durability of four paints (acrylic isocyanate, polyester melamine, polyester isocyanate, and alkyd), Surface Coatings International Part B: Coatings Transactions Vol. 80, No.2, pp.367-372.

Guin, A. K. Nayak, S. K. Rout, T. K. Bandyopadhyay, N. Sengupta, D. K. (2011). Corrosion behavior of nanohybrid titania-silica composite coating on phosphated steel sheet, J. Coat. Technol. Res., online since 24 Feb.

Gysau, D. (2006). Fillers for paints: fundamentals and applications, p. 32, European coatings literature.

Herbst, W. and Hunger, K. (2006). Industrial organic pigments, Chap. 1, p. 143, Wiley VCH, $\mathrm{GmBH}$.

Hernández, L.S. Del Amo, B. and Romagnoli, R. (1999). Accelerated and EIS tests for anticorrosive paints pigmented with ecological pigments, Anti-Corrosion Methods and Materials Vol. 4, No. 2, pp. 198-204.

Huang, Y. Shih, H. Huang, H. Daugherty, J. Wu, S., Ramanathan, S. Chang, C., and Mansfeld, F. (2008). Evaluation of the corrosion resistance of anodized aluminum 6061 using electrochemical impedance spectroscopy (EIS), Corrosion Science Vol. 50, No. 5, pp. 3569-3575.

Kendig, M. Mansfeld, F. Tsai, S. (1983). Determination of the Long Term Corrosion Behavior of Coated Steel with A.C. Impedance Measurements, Corrosion Science Vol. 23, No. 3, pp. 317-329. 
Kirubaharan, A. M. K. Selvaraj, M. Maruthan, K. Jeyakumar, D. (2009). Synthesis and characterization of nanosized titanium dioxide and silicon dioxide for corrosion resistance applications, J. Coat. Technol. Res. Vol. 21, online since 25, Nov.

Lambourne, R. (1987). Paint and surface coatings, p. 131, Ellis Horwood Ltd. Pub.

Martens, C.R. (1974). Technology of Paints, Varnishes, and Lacquers, p. 344, Robert. E. Krieger Publishing Co., Melbourne, FL.

Mirabedini, S.M. Thompson, G.E. Moradian, S. Scantlebury, J.D. (2003). Corrosion performance of powder coated aluminium using EIS, Progress in Organic Coatings Vol. 46, No. 2, pp. 112-120.

Molera, P. Oller, X. Del Valle, M. and Gonzalez, F. (2004). Formulation and characterization of anticorrosive paints, Pigment E Resin Technology Vol. 33. No. 1, pp.99-104.

Otterstedt, J.E. Brandreth, D.A. (1998). Small particles technology, Chap. 4, pp. 176-178, Technology and Engineering.

Patton, T.C. (1973). Pigment handbook, p. 199, Wiley-Interscience publication.

Perera, D.Y. (2004). Effect of pigmentation on organic coating characteristics, (review), Progress in Organic Coatings Vol. 50, No. 1, pp.247-262.

Peter, H. and Robert, V. (1999). High grade kaolin fillers-production review: Industrial Minerals, Vol. 54, pp 25-37.

Salamone, J.C. (1999). Concise polymeric materials encyclopedia, p. 477, CRC press.

Shao, Y. Jia, C. Meng, G. Zhang, T. Wang, F. (2009). The role of a zinc phosphate pigment in the corrosion of scratched epoxy-coated steel, Corrosion Science Vol. 51, No. 1, pp. 371-379.

Siddique, R. and Khan, M.I. (2011). Supplementary Cementing Materials, Chapter 2, pp. 67117, Engineering Materials, Springer-Verlag Berlin Heidelberg.

Sorensen, P.A., Kiil, S. Dam-Johansen, K. and Weinell, C.E. (2009). Anticorrosive coatings: a review, J. Coat. Technol. Res. Vol. 6, No. 1, pp.135-176.

Streitberger, H.J. and Kreis, W. (2008). Automotive paints and coatings, p. 144, Science and Technology publishing.

Talbert, R. (2007). Paint technology handbook, p. 61, Taylor \& Francis Inc.

Veleva, L., Chin, J. and Del Amo, B. (1999). Corrosion electrochemical behavior of epoxy anticorrosive paints based on zinc molybdenum phosphate and zinc oxide, Progress in Organic Coatings Vol. 36, No. 2, pp. 211-216.

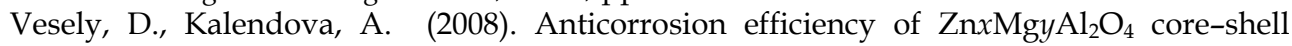
spinels in organic coatings, Progress in Organic Coatings Vol. 62, No.1, pp. 5-20.

Walter, G.W. (1991). Laboratory Simulation of Atmospheric Corrosion by $\mathrm{SO}_{2}$-II. Electrochemical Mass Loss Comparisons, Corrosion Science Vol.32, No. 5, pp. 13531359.

Warson, H., Finch, C.A. (2001). Applications of synthetic resin lattices: Lattices in surface coatings, p. 172, Technology and Engineering.

Weil, T.C. (2011). Addressing Parking Garage Corrosion with silica Fume, Transportation Research Record 1204, pp. 8-10, W. R. Grace \& Company, Construction Products Division, Cambridge, Mass.

Xianming, S. Nguyen, T.A. Zhiyong, S. Liu, Y. and Avci, R. (2009). Effect of nanoparticles on the anticorrosion and mechanical properties of epoxy coating, Surface $\mathcal{E}$ Coatings Technology Vol. 204, No.1, pp. 237-245.

Yingchao, Z. Hongqi, Y. Hui, L. Kai, H. (2011). Preparation and characterization of aluminium pigments coated with silica for corrosion protection, Corrosion Science, article in press. 


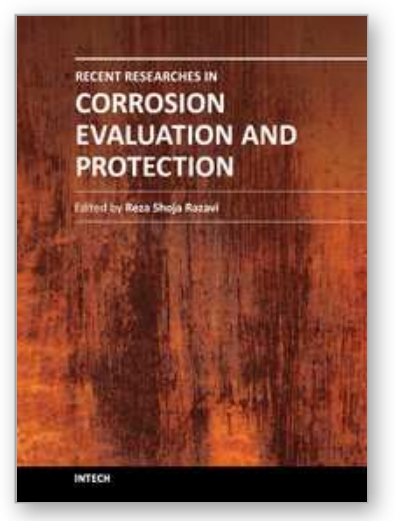

\section{Recent Researches in Corrosion Evaluation and Protection}

Edited by Prof. Reza Shoja Razavi

ISBN 978-953-307-920-2

Hard cover, 152 pages

Publisher InTech

Published online 25, January, 2012

Published in print edition January, 2012

The purpose of this book is to present and discuss the recent methods in corrosion evaluation and protection. The book contains six chapters. The aim of Chapter 1 is to demonstrate that Electrochemical Impedance Spectroscopy can be a very useful tool to provide a complete evaluation of the corrosion protection properties of electro-coatings. Chapter 2 presents results of studies of materials degradation from experimental electrochemical tests and theoretical calculations. Chapter 3 deals with the presentation of the corrosion and corrosion prevention of the aluminum alloys by organic coatings and inhibitors. Chapter 4 addresses the new method of pigment preparation that can improve protection efficiency. The effectiveness of plasma deposited films on the improvement of carbon steel corrosion resistance is discussed in Chapter 5. Chapter 6 deals with the conjugation of carbon nanotubes with organic-inorganic hybrid to prepare hybrid coatings that combine high anti-corrosion efficiency with elevated mechanical resistance.

\section{How to reference}

In order to correctly reference this scholarly work, feel free to copy and paste the following:

Nivin M. Ahmed and Hesham Tawfik M. Abdel-Fatah (2012). The Role of Silica Fume Pigments in Corrosion Protection of Steel Surfaces, Recent Researches in Corrosion Evaluation and Protection, Prof. Reza Shoja Razavi (Ed.), ISBN: 978-953-307-920-2, InTech, Available from: http://www.intechopen.com/books/recentresearches-in-corrosion-evaluation-and-protection/the-role-of-silica-fume-pigments-in-corrosion-protection-ofsteel-surfaces

\section{INTECH}

open science | open minds

\section{InTech Europe}

University Campus STeP Ri

Slavka Krautzeka 83/A

51000 Rijeka, Croatia

Phone: +385 (51) 770447

Fax: +385 (51) 686166

www.intechopen.com

\section{InTech China}

Unit 405, Office Block, Hotel Equatorial Shanghai

No.65, Yan An Road (West), Shanghai, 200040, China

中国上海市延安西路65号上海国际贵都大饭店办公楼 405 单元

Phone: +86-21-62489820

Fax: $+86-21-62489821$ 
(C) 2012 The Author(s). Licensee IntechOpen. This is an open access article distributed under the terms of the Creative Commons Attribution 3.0 License, which permits unrestricted use, distribution, and reproduction in any medium, provided the original work is properly cited. 